\title{
To Revive Delight: A Poet's Restaurant Reviews in Early 1990s Prague
}

\begin{abstract}
In 1993, the Prague-based newspaper Lidové noviny (The People's News) ran a short-lived restaurant review column, Básník má hlad (The Poet Is Hungry). The author was Petr Král, a poet and essayist who had recently returned to Prague after two decades of exile in Paris. In this article, I contextualize Král's restaurant reviews within his oeuvre and in the history of Czech restaurant culture. The first half describes the evolution of restaurants in Czech culture and literature from the First Czechoslovak Republic through the communist period. The second half is devoted to close readings of Král's restaurant reviews.
\end{abstract}

anyone who has been to Prague in recent years will have enjoyed a vibrant restaurant industry. In addition to Czech restaurants whose sandwich boards beckon tourists with traditional Bohemian cuisine, one finds several exciting additions to the culinary scene: three Michelin-starred establishments, a multitude of international dining options, and a variety of choices for the vegetarians who, until recently, were confined to fried cauliflower appetizers. Most tellingly for the rise of foodie culture is the appearance of "New Bohemian" cuisine, upscale and upsold reimaginings of classic Czech dishes. There is an unlikely hero behind the development of the Czech restaurant industry (which is not to say Czech cuisine). $\mathrm{He}$ is not a chef or even an entrepreneur but a poet.

In the early 1990 following the fall of the communist regime, the identity and priorities of the newly established Czech Republic were up for debate. The main concerns of the poet Petr Král emerged when, dining at a tavern, he tried to send back a plate of štěpánská, a dish of roast beef with hardboiled eggs, that he found too dry:

In protest my waiter indeed took the food back, the criticism however he haughtily denied: every chef simply did it a little differently and everyone else who ordered it found it tasty. His haughtiness was all the more annoying because it did not reflect only his personal position, but two typical abuses of Czech "hospitality" in general. Above all, an unwillingness to understand that good restaurants must make various chefs restrain from their personal styles - not to offer under one name dishes so different that ordering it every time is like buying a lottery ticket. Even more dangerous is of course the inability to take criticism; in
I find that they are consistent with the restorative nature of the Czech political and economic transition after communism. To Král, the restaurant represents a microcosm of society. Thus, in the spirit of restoration and revitalization, he elevates the genre of restaurant reviews, infusing them with political urgency and a sense of poetry.

Keywords: Prague, restaurant reviews, postcommunism, poetry, surrealism

a normal restaurant, even if they defended themselves, they would still endeavor to appease the guest. ("Vinárna U rarášků," October 2)

The excerpt comes from Král's restaurant review series Básník má hlad (The Poet Is Hungry), which ran sporadically in the weekend editions of the popular daily newspaper Lidové noviny (The People's News) from July through December of 1993. In it, he imagines restaurants as a potential locus of art and civil society, advocating for the restoration of values that he felt had been eroded during a half century of communism.

The excerpt above contains two phrases that are crucial to understanding Král's project: "typical abuses" and "in a normal restaurant." For Král, the restaurant is a microcosm of society, and the "typical" unrefined behavior he encounters there seems to him endemic in postcommunist Prague. The other key idea is the implicit disparity between the restaurant he is reviewing and "a normal restaurant." Although the series is unconventional in many ways, it is not oriented toward culinary innovation or revolution, but rather toward restoring normalcy. Drawing on gastronomic culture from both Czech history and contemporary Western Europe, namely France, Král's goal is to reestablish pre-communist cultural mores in the Czech restaurant industry.

While the reviews, eleven in total, form an extremely small sampling, the series stands as an innovative artistic interpretation of the nation-building project that was taking place throughout the Czech Republic. It was also a novel venture by a major poet who had recently returned home after a lengthy exile in France. 
Král's decision to turn his attention to the restaurant industry suggests an expansive conception of art and politics. His selfstyling as a restaurant critic reflects not only his gourmet palate but also his poetic sensibility, characterized by his ability to perceive sublime dimensions in the everyday realm.

In this article, I analyze the goals and methods of the poet's temporary stint as a restaurant critic. I argue that he elevated the genre of restaurant reviews, infusing them with artistic devices and political gravitas, in an attempt to reawaken the creative and civic potential in the newly dawned postcommunist era. Because for him the restaurant functions as a metaphor for society at large, the true scope of his seemingly modest newspaper column was indeed monumental.

\section{Gastronomy in Czech Literary Culture: A Brief Overview}

Through Básník má hlad, Král promoted aesthetic values, unbound by communist constraints, to which he had been exposed during his time in France and which he believed could take root in the Czech Republic. However, contemporary France was only one of his two main reference points. Crucially, Král advocates for restaurants to reclaim their status as sites of important cultural activity. This suggests that Král drew inspiration from the First Czechoslovak Republic (191838; henceforth "the First Republic"), which loomed large in the popular imagination in the early 1990s. The First Republic was a high-water mark for the Czech restaurant industry as well as art and literature. It was the era during which Karel Čapek, Franz Kafka, and Jaroslav Hašek, among others, created their seminal works. But most importantly for Král's project, and for many other Czech thinkers in the early 1990s, the First Republic was a functioning democracy. Newly independent after the dissolution of the Habsburg Empire, the First Republic with its capital in Prague was the long-sought-after goal of generations of writers, scholars, and politicians in the region. This legacy helps to account for the restorative nature of the Czech transition after communism (Smith and Jehlicka 2007; Ash 2009). In defining the new Czech Republic in the early 1990s, many in Prague took a page from their own history.

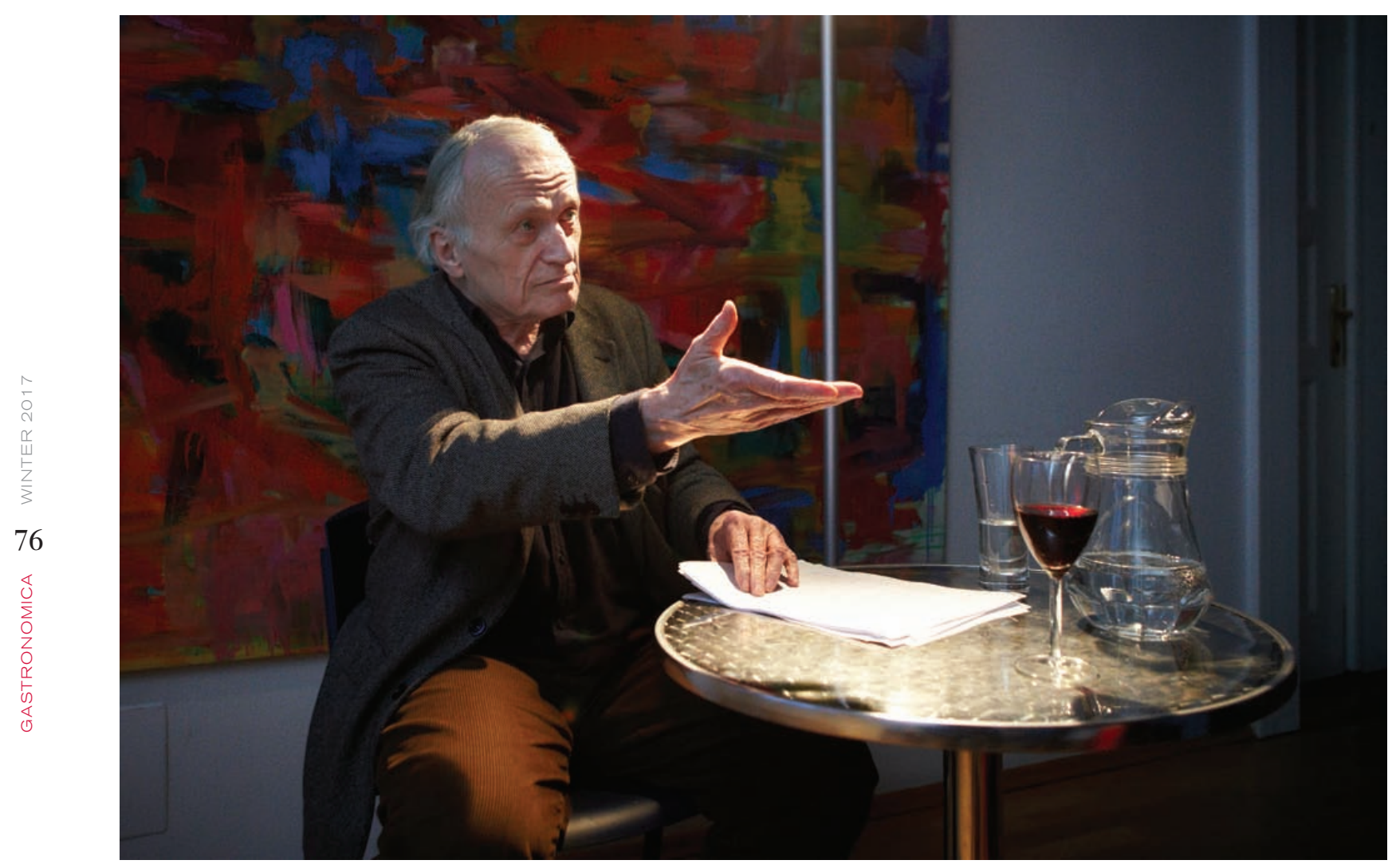

Figure 1: The poet Petr Král.

PHOTOGRAPH BY ONDŘEJ NĚMEC/VÁCLAV HAVEL LIBRARY, 2013 
Král's restaurant reviews were, in a playful way, his contribution to this project of national self-definition. Básník má hlad, intended to inspire restaurant-goers and energize the industry, aims at eradicating some remains of communism by reestablishing Prague's European gastronomical tradition. For Král the art of reviewing restaurants is about much more than the search for the next great bite; at stake is the aesthetic revival that accompanied the political transition.

Král, who was born in 1941, is today a member of a group that congregates at the Literární Kavárna [Literary Coffeehouse] Řetězová in Prague's Old Town. The klatch is composed of a rotating cast of prominent writers, architects, and filmmakers, among others, all male and mostly around Král's age. For several years, they have spent every Friday afternoon at the bar-restaurant, where they feast, drink, reminisce, and lovingly tease each other. ${ }^{1}$ The poet Ivan Wernisch, who is also a member, nicknamed the group pátečníci or "Friday men" (Ditrych 2009), a reference to the Friday salons hosted by the writer Karel Čapek during the First Republic, which welcomed illustrious artists and statesmen, including then president T. G. Masaryk (Orzoff 2009). By this homage Wernisch irreverently or ironically locates the Řetězová circle within the history of Czech intellectual and cultural discourse.

As Král, reputedly one of the best cooks in the bunch, explains during an interview about the group,

For me, the joy of eating in and of itself consists not in surprise but in simple satisfaction, in the fact that I am encountering a favorite taste in its optimal form. That joy differs from love of poetry, although it is close. If a poem is true poetry, it must be revelatory. But for food, it is enough to fulfill expectations, conform to custom and revive delight. (Ditrych 2009)

The group has published two books, the elliptical titles of which read like someone ordering or serving dessert: ...a rakvička se šlehačkou [....and a pastry with whipped $\mathrm{cream}^{2}$ ], 2008, and .... nakonec kafe s malym [... and finally coffee with a dash], 2011. The books are collections of food writing, recipes, and the menu from each Friday's lunch, and Král's contributions represent his more recent food writings. Known primarily as a poet with ties to the second wave of Czech surrealism, he is also an accomplished essayist, screenwriter, memoirist, and translator. Král's interest in food spans the various genres in which he works; even his book of film criticism, Groteska čili Morálka šlehačkového dortu [The grotesque or the morality of cream cake], includes a chapter on food in silent comedies.

Food occasionally appears in Král's poetry as well, such as "Memory of a Poem-Excursion" from 1967, the height of the poet's surrealist phase (quoted here in its English translation by James Naughton). The speaker claims that "[o]ne of my most successful poems concerned my striking dislike for poetry." He goes on to rail against the euphemistic nature of poetry, in which "the word shit is replaced / by the word violin the word coffeehouse by barracks / pleasure by the word castration the word back-side by book / the word book by sausage / even the word egg by egg." In the next stanza, he tells how "[d]isgustedly I turned away from shit I grabbed a sausage / and began to read." In this poem, the messy material reality of life, including food and its inevitable by-product, excrement, intrudes into the idealized world of poetry. By introducing these elements into a poem that is ultimately about the drive for artistic creation, Král creates a poetic persona that navigates between idealization and reality. At the same time, he transforms the everyday into artistic material, not unlike Dalîs repurposing of bread and corn for Retrospective Bust of a Woman, 1933.

That two of Král's main artistic inclinations, surrealism and Francophilia, emerged early in his career made them mutually galvanizing. In the late 196os, Král was a major figure in the second wave of Czech surrealism (Sayer 2013). Following the Soviet invasion of Prague in August 1968, Král and several other Czech writers and artists fled to Paris seeking refuge and, perhaps, creative resonance. ${ }^{4}$ Included in this group was the poet Stanislav Dvorský, today a member of the Pátečníci. Most of Král's friends returned to Czechoslovakia after a few months in France, while he remained in exile. He stayed mainly in Paris throughout the extended Soviet occupation, writing and publishing poetry in both Czech and French. He also continued to promote contemporary Czech literature through translation and literary collaboration. The influence of surrealism on his poetry became less pronounced as the 196os came to an end, but the potential magic of the everyday remained an important theme.

Following the 1989 Velvet Revolution, Král served as cultural councilor of the Czechoslovak embassy in Paris in 1990 and 1991 before finally returning to Prague. ${ }^{5}$ In 1993, a few months after the Czech Republic and Slovakia declared mutual independence in the so-called "velvet divorce," Král began his project of introducing a novel breed of restaurant reviews to the Prague readership, and to the languishing Prague restaurant world. This was surely an unexpected move from such a highly regarded poet, and to this day the series is not counted among Král's best known or most respected works. However, the reviews are not only consistent with his artistic style and interests, they also concern the most important sociopolitical questions of the day. The unassuming genre of the restaurant review became Král's vehicle for diagnosing Czech society in the immediate postcommunist era.

In his mission statement, quoted below, Král explains that restaurant reviews were rare in Prague. Unusually for a restaurant critic, Král did not assign himself the task of reviewing 
newly opened restaurants. Instead he discussed familiar dining establishments, many of which had been in operation since before the regime change, with a new vocabulary and critical bent. Having acquired in Paris a taste not necessarily for fine dining but for dining as an artistic experience, Král returned to Prague with higher standards than what the slapdash kitchen of a communist-era canteen could satisfy. His expectations had less to do with food per se than with a unified restaurant experience marked by care and intentionality. He wanted to approach the restaurant meal as a work of art.

The grandiose Czech restaurant industry reached its zenith during the First Republic. In Prague, magnificent Art Nouveau buildings housed elegant dining rooms, while in the Bohemian countryside natural mineral springs gave rise to luxurious spa-hotels. Bohumil Hrabal's novel I Served the King of England, written in 1971 but not published in the official Czech press until 1983, depicts restaurant culture in the First Republic, and traces its changes during the Nazi occupation and communist era. It follows the professional and personal development of Jan Dítě, a waiter and aspiring hotel-owner whose life plays out against the regime changes that defined the twentieth century. Dítě's life in the restaurant industry brings him into contact with traveling salesmen, prostitutes, a Masaryk-like president, an emperor of Ethiopia, Nazis, communists, and a hard-to-please general who

took an oyster from the plate, threw his head back, and eagerly swallowed the slimy flesh sprinkled with lemon juice, and again he seemed to eat with gusto, but no, he shuddered and snorted with disgust, his eyes watering. He downed his glass of champagne and shouted, Aaaaaa, I can’t drink this swill! (Hrabal 2007: 61)

Dítě's encounters are, as in the characteristic quote above, by turns charming and grotesque. As his relationships with guests and colleagues force him to reevaluate his own goals and character, the restaurant world becomes a backdrop for a bildungsroman. In the novel, as in Král's reviews, the restaurant is a microcosm of culture, a place where norms in business, politics, and leisure are on display.

Under the communist system, both agriculture and restaurants were nationalized, and cafeterias, workplace canteens, and affordable beer-halls came to predominate over elegant eateries. However, fancy establishments were not eradicated, but rather refashioned in accordance with communist ideology. Cultural anthropologist Iveta Hajdáková, whose work echoes Hrabal's novel, argues that service industry jobs in the First Republic were valued and respected professions. However, in the communist era, these jobs offered few advantages other than access to easily pilfered foodstuffs, and professional standards for cooks and waiters were systematically lowered (Hajdáková 2013). Spa-hotels, once the exclusive province of the wealthy elite, were rebranded as part of Czechoslovak national heritage, and workers were encouraged to visit them during their annual paid vacations (Soukupová 2003).

Restaurants were divided into four price groups, the first group being the most expensive and the fourth the cheapest. Group one restaurants, many of them housed in hotels, boasted uniformed waiters and sometimes offered international cuisine featuring rare ingredients. Although such establishments retained the air of exclusivity, the standardization of prices and wages meant that the average person could afford to visit even a group one restaurant from time to time. This can be seen in Věra Chytilová's 1966 New Wave film Daisies, when the young food-crazed heroines are treated to dinner in fancy restaurants by their suitors. Most of the restaurants in Prague were casual eateries in the third price group. But perhaps even during the period of a nationalized restaurant industry, this classification system was insufficient. ${ }^{6}$ In an essayistic Prague guidebook written in exile, Král (2000: 75) laments that the "gamut of Prague hospody [pubs] in its richness certainly exceeds the existing official division into four price groups."

Indeed, throughout the communist era, food was a useful symbol for both the successes and failures of the regime (Caldwell 2009). Promises of affordable, nutritious food prepared and enjoyed communally belied the reality of lowgrade canteens, empty store shelves, and endless queues for basic ingredients. Food shortages affected private individuals and restaurateurs equally, although high-ranking Party members and the kitchens that served them were often "first among equals." In the postcommunist era, no longer at the mercy of shortages and an unmotivated workforce, Praguers were in a position to enjoy sophisticated gastronomy. But if pre-communist norms were to be restored, both producers and consumers had to adopt new standards. Food could once again be employed as a useful symbol in reestablishing Prague as a cultural capital. This time, however, meaning would be assigned by entrepreneurs, restaurant-goers, and one epicurean poet.

Although often obscured by legend and cliché, the importance of pubs and restaurants in Czech literature and literary history is not to be understated, and Král's project must be understood in this context. Prague literary circles have historically been associated with the cafés at which they gathered. In the 1910s and 1920s, the Cabaret Montmartre in Old Town was the usual meeting place and performance space for Jaroslav Hašek's circle. During the same period, Kafka and other luminaries of the German-speaking Jewish intellectual 
community could often be found at Kavárna Arco in Prague's New Town. Another iconic establishment is Café Slavia, founded in 1884 . In the 196os, Slavia was the favorite hangout of the circle of artists and writers that included Jiří Kolár, Jaroslav Seifert, and Václav Havel. ${ }^{7}$ That was a time of political and artistic liberalization, culminating in the Prague Spring of 1968. The Soviet invasion in August of that year put an end to the liberalization movement and initiated the repressive "normalization" period. During this time, when censorship and other forms of artistic and media control were reinstated, Havel and fellow dissidents continued to gather at Slavia. The 2008 documentary Citizen Havel shows the president-playwright launching a sardonic political campaign to restore Slavia, playing on the café's historical legacy as well as the literal meaning of its name: glory.

The transformation of Café Slavia from an artists' and intellectuals' meeting place to an overpriced tourist destination is a familiar narrative. The international popularity of Hašek's masterpiece The Good Soldier Švejk has given rise to an insipid industry of vaguely Švejk-themed bars. Král himself devoted an essay to the fate of Kavárna Arco. He describes a dingy dive, frequented by crooked policemen and brazen criminals, where only "the beverages of the drink menu suggest the legendary past: Milena Jesenská hot chocolate (egg liqueur, whipped cream), Franz Kafka hot chocolate (rum, whipped cream)" (Král n.d.). Now out of business, Kavárna Arco still functions as a pilgrimage site, where Kafka devotees eagerly peer through the café's windows into a dismal empty space. Perhaps only at U Zlatého Tygra [At the Golden Tiger], the bar favored by Hrabal until his death in 1997, is the historico-literary legacy successfully managed. Although photos of Hrabal on the walls testify to his association with this bar, it remains unpretentious and affordable. The uniform rudeness of waiters at U Zlatého Tygra to guests who do not speak Czech serves to defend against Prague's latest occupying force: tourists. These days the weekly meetings of Král and his pátečníci at the restaurant on Řetězová may be motivated at least in part by a nostalgic yearning for the heyday of literary café culture.

With his restaurant reviews, Král inconspicuously positioned himself to become a culinary trendsetter. The fact that he presented this project in an accessible format, publishing in the daily newspaper Lidové noviny rather than, say, a literary journal, corresponds with the way he branded himself as a non-elite gourmet. In fact, the choice of Lidové noviny, popularly called Lidovky, points to Král's historical orientation. Founded in 1893, it is the oldest Czech daily, and during the First Republic it featured the work of Masaryk, Čapek, and other original pátečníci. The paper was closed in 1952 during the most repressive period of communist rule, but enjoyed a remarkable second life in the late 1980s when it was revived in the samizdat (self-publishing) press. Dissidents such as Havel, Eva Kantůrková, and Milan Šimečka contributed to Lidovky in its new unofficial configuration. Officially reopened around the

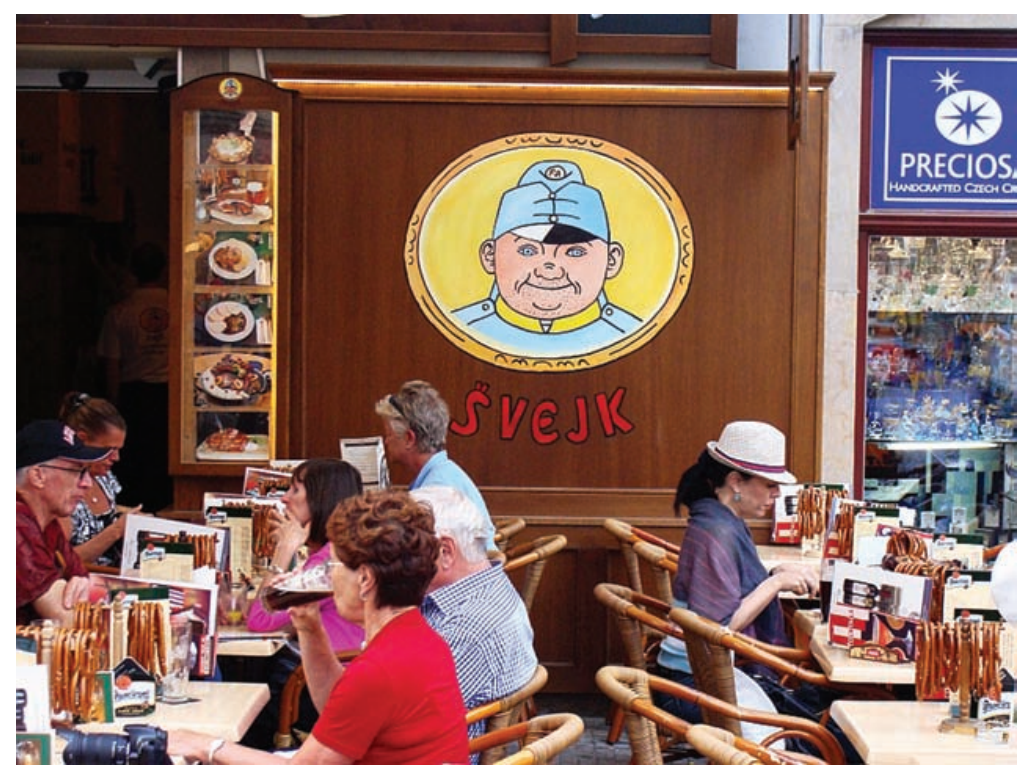

Figure 2: A Švejk-themed bar in Prague.

BY SILAR (OWN WORK, 2012), CC BY-SA 3.0, PUBLIC DOMAIN, HTTPS://COMMONS.WIKIMEDIA.ORG/WIKI/FLLE:08460_DAS_SCHEJK_ RESTAURANT_IN_PRAG.JPG, VIA WIKIMEDIA COMMONS 
time of the Velvet Revolution, the paper now has neither an overt political affiliation nor an artistic bent, but it remains a popular daily print newspaper with a strong online presence.

In his reviews, Král suggests that the best restaurants are not necessarily fancy ones, but rather modest eateries serving reliably good food at reasonable prices. Král's preference for simple foods accords with his broader poetic concern: an aestheticization of the everyday. Crucially, throughout the series, food is only one of Král's interests, and in fact it is rarely his focus. More important to him is that restaurants exhibit certain values that he believes vanished under communism: accountability, consistency, and aesthetic intentionality.

\section{Král's Restaurant Reviews: Politics and Poetry}

On Sunday, July 10, 1993, Král published his mission statement, quoted below in its entirety:

Gastronomic reviews do not have a great tradition in our newspapers. This is no trivial matter; hospody [pubs] are exemplary sites of the clash of the old regime with the new emerging lifestyle. If they are not to be just kantýny [canteens] and money-making machines, if they are instead to be an important forum where a fundamental part of private and public life takes place out in the open, we must subject the dominant vulgarity, in both its traditional and new forms, to an offensive of opposing values: freedom, resourcefulness, attention to people and things. Supposedly extravagant qualities like epicureanism, elegance, and a sense of poetry can play important roles here. Sometimes it is enough that restaurants create awareness of some old but fundamental truth.

The guiding principle of this small chronicle, which will be presented weekly, is the cohesiveness of hospodsky [pub] experiences. Culinary art is essentially the unifying of tastes, so the art of running a hospoda consists in the ability to create a harmonious whole. The taste of food and drinks should complement the behavior of the servers, the furnishing of the dining room, and the atmosphere of the space itself. A restaurant-like a poem for Baudelaire-is a space where corresponding "sounds, colors, and scents" join into a complete symphony, giving a unique taste to our very existence.

The worst consequence of the communist regime is that they taught us to disdain ourselves. The habit of neglecting ourselves with regards to food and to the "quality of experiences" overall, passively suffering what is offered and expecting nothing from it, is the direct result of the humiliation to which the old regime accustomed us. It is the seed of death which they sowed in us. The attempt to once again make hospody into places of excitement, desire, and satisfaction is also the attempt to bring back lost human dignity. ("Básník má hlad," July 10)

In spite of Král's penchant for melodrama, betrayed in the final paragraph and recurrent throughout his reviews, this project was thoughtfully conceived and thoroughly executed. His identification of self-loathing as the main legacy of the communist regime gives gravity to his project overall. When he describes "the habit of neglecting ourselves," he may be referring to small portions, lack of access to quality ingredients, or the erosion of hospitality as a value. Král suggests that this neglect systematically lowered people's expectations, transforming restaurant dining from a delightful experience into a humiliating one. The restaurant, when understood as a place where people intentionally practice the cultural values of refinement and erudition, can be reclaimed as a site of crucial civic activity. Connecting the revitalization of the restaurant industry with the restoration of human dignity, Král's project becomes one of social necessity.

In his lofty estimation of the function of gastronomy, Král recalls Bourdieu, who describes "the taste of liberty-or luxury - which shifts the emphasis to the manner (of presenting, serving, eating, etc.) and tends to use stylized forms to deny function" (Bourdieu 1984: 6). In both Bourdieu's and Král's conceptions, a proper meal is the elevation of food to a work of art. Just as the relationship between the visual and ontological is a major theme in his poetry, Král's interest in gastronomic aesthetics conceals his deeper concerns: the reestablishment of intentionality and artistry in the public sphere. In the final paragraph quoted above, the revitalization of the restaurant industry is tied to the reestablishment of values, civic and aesthetic, in the new postcommunist era.

Král's project, then, is not to redefine restaurants, but to return to restaurants their original definition. For a model restaurant industry, Král draws on the French establishments he patronized throughout his years in exile. In a book-length interview with literary critic Radim Kopáč published in 2006, Král discusses his various "journalistic-cultural initiatives" of the early 1990s, explaining, "I even started to print restaurant reviews, thinking that I could share some of my French gastronomic experience" (Kopáč 2006: 148-49).

Some ten years before Král's restaurant reviews, Milan Kundera published the landmark essay "The Tragedy of Central Europe" in the French journal Debáts in 1983; it was translated for the New York Review of Books the following year. In it, Kundera, who emigrated permanently to France in 1975 , decries the international indifference to the erasure of distinct and essentially heterogeneous Czechoslovak, Polish, and Hungarian cultures, as this "uncertain zone of small nations between Russia and Germany" was brought under the homogenizing power of the Soviet Union (Kundera 1984: 35). There can be little doubt that Král read the essay, probably in its original French publication. Kundera's idea that "in Central European revolts there is something conservative, nearly anachronistic: they are desperately trying to restore the past, the past of culture, the past of the modern era" (ibid.: $3^{8}$ ) anticipates the restorative orientation of Básník má hlad. Král advocates for Czech national development along the lines of a return to European 
culture, interrupted but not annihilated by the communist era. Unlike Kundera, however, Král associates "Europeanness" specifically with the French aesthetic, and in this he is not alone. In the preface to Distinction, Bourdieu (1984: xii) notes with false modesty that taste is essentially a French invention.

Král's egalitarian approach to restaurant criticism was partially a matter of necessity, writing about modest neighborhood eateries simply because there were no exciting new restaurants to review at that time. Although Prague was home to the first Michelin-starred restaurant in the former Soviet sphere, the now-closed restaurant Allegro did not earn the accolade until 2008. And yet Král does not let a lack of material turn into a lack of inspiration. On the contrary, he writes specifically about restaurants that are not particularly noteworthy, and often just plain lousy. This is consistent with the trademark of Král's poetics, a focus on the mundane. What's more, his jocular vitriol is among the great pleasures of the series.

A typical negative review, for example, charges that the restaurant Beseda Bonsai garnishes its goulash with "a handful of appalling mixed pickles, daintily dumped cold onto the plate, right from the ashtray" ("Beseda Bonsai," December 4). His style reveals the full comic potential of scare quotes, as seen in his description of the staff at Bistro Bárta, where the "server along with the 'chef'-more likely only the heater-upper of food-are unfortunately two cranky ladies who do not lend the business anything more than their half-dead bodies" ("Bistro Bárta," August 17). When discussing food, he decries style without substance, and on the topic of service, reviles carelessness and apathy. Along with disproportionately high prices, he considers the use of microwaves and the absence of toothpicks to be cardinal sins. In each review, he praises whatever strengths a given restaurant may show, but collectively, the series issues a challenge to the industry at large.

\section{Bouillon D'or}

In his short tenure as a restaurant critic, Král reviewed nine eateries in Prague, one in Brno, and one in Paris, but his piece on the Parisian Bouillon Chartier is more like a nostalgic prose-poem than a proper review. Chartier and the Czech restaurants Král praises share a commitment to simple and traditional dishes, prepared with quality ingredients and served with care. However, it is important to keep in mind that as an intellectual newly returned from Paris and chiefly concerned with restaurants in the national capital, Král enjoyed an elite position that risked estranging him from his readers. He acknowledges this in the interview with Kopáč: "My taste for sharing my findings often aroused less interest than suspicion, as if I came to Bohemia to show off and taunt people with the fact that, while they stewed in their own juices, I enjoyed and collected brilliant experiences" (Kopáč 2006: 148-49). The mission statement of the series quotes Baudelaire and indeed, despite his self-styling as a man of the people, Král is something of a gastronomic flâneur, making an art out of indulging himself.

Král's review of Chartier is unique in the series, being both the only review about a non-Czech restaurant and the only completely positive one. But an analysis of it is instructive because this review establishes Král's standards for a superb dining experience, the likes of which he could not find in Prague at that time, and because it reveals the literariness of his project. The Chartier review, which appeared toward the end of the series, has the unmistakable flavor of Proustian longing. When he places the restaurant in the context of the "historic consciousness" of the city and innumerable globetrotters who have passed through it" ("Chartier," October 16), Chartier becomes important less as a restaurant than as a lieu de memoire.

His writings from and about Paris betray a reverence for the city's grand artistic legacy, but Král seems to have been just as in tune with its workaday delights. In 2012 he published Cahiers de Paris, a charmingly discursive journal with entries from 1968 to 2006 . This is not a diary of events but rather a collection of momentary impressions, ranging in length from one word to a few sentences. One surrealistic gem of an entry from 1969 reads "Steak haché Charlotte Corday" (Král 2012a: 26); the chance meeting of ground beef and an assassin from the French Revolution functions as a metaphor for the poet's conception of Paris: the extraordinary infuses the everyday.

The review of Chartier begins with a detailed description of its interior. This differs somewhat from the reviews of Czech restaurants, whose introductory paragraphs are always devoted to precise explanations of the locations, only after which does the critic venture inside. Král may have imagined that visiting the Czech restaurants was a realistic prospect for his readers in Prague while Chartier is, for both the author and his intended audience, an ideal toward which to strive. Significantly, Král does not present Chartier as unique, at least not for Paris. He repeatedly emphasizes the fact that it is a typical bouillon, a type of casual eatery (literally a soup kitchen) that arose in France in the late nineteenth century. The restaurant's website states: "In 1896, the Bouillon Chartier was born out of a very simple concept-provide a decent meal at a reasonable price and give customers good service in order to earn their loyalty." This description could have been written by Král himself. 


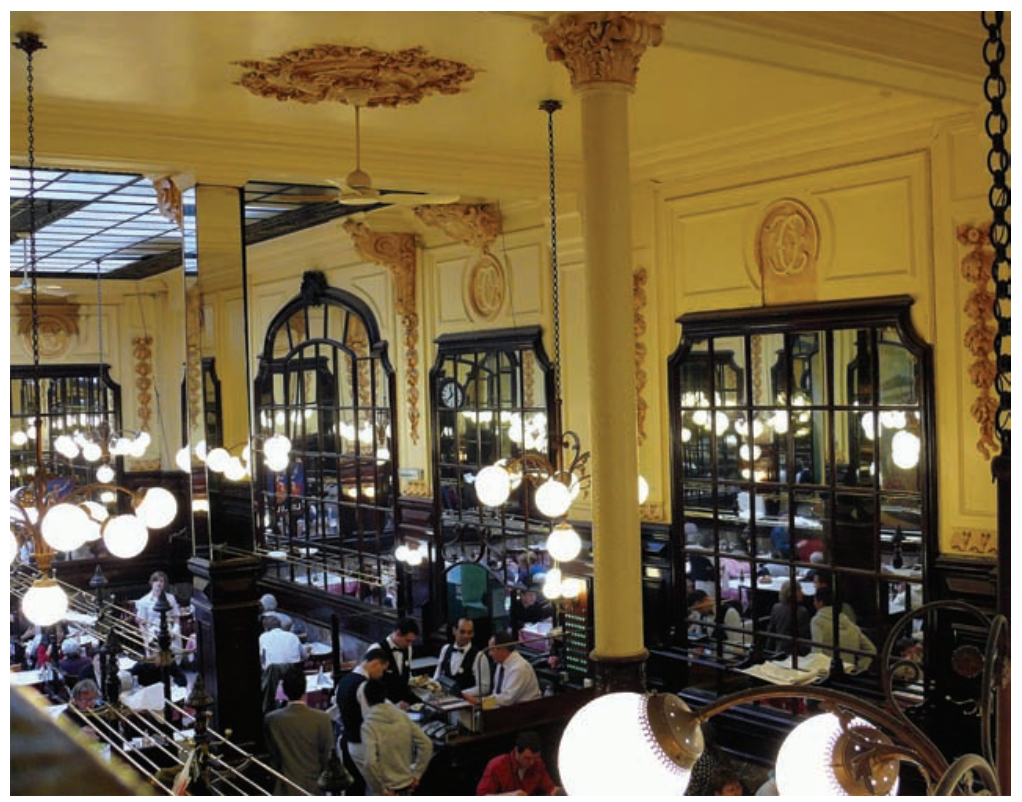

Figure 3: Bouillon Chartier in Paris.

BY MOSSOT (OWN WORK, 2009), CC BY-SA 3.0, PUBLIC DOMAIN, HTTPS://COMMONS.WIKIMEDIA.ORG/WIKI/FILE:BOUILLON

CHARTIER_-2.JPG, VIA WIKIMEDIA COMMONS

The following lines from Král's review essentially encapsulate his definition of a good restaurant:

Even if the food at Chartier is not exactly exquisite, that doesn't mean that they serve any old thing. On the contrary, an invisible but fundamental bond connects a bouillon with the "great" Parisian restaurants, which actually only refined the traditional "folk" basis of the entire French cuisine. ("Chartier," October 16)

He takes issue with the international reputation of French cuisine, which he considers erroneous, rejecting "the misrepresentative cliché, according to which French cuisine is 'subtle.' ...[Y]ou see, what is subtle about the way they eat in France is not in the food, but in the style, the cooking, and the dining itself" (ibid.). The menu at Chartier features rustic fare like grilled steak, herring with potato and escargot, and "little brains with 'black' butter, which I like to order here (usually after the celery salad)" (ibid.). By stripping French gastronomy of its reputed delicacy, Král aligns it with hearty, unpretentious traditional Czech cuisine.

The Chartier review showcases Král's frugality, a rare quality among gourmets, let alone restaurant critics. He praises Chartier's "incomparably low prices" (ibid.) for appetizers and drinks and, cautioning that the steaks' low prices accurately reflect their quality, recommends the humble ragù. Even though the Chartier review is on some level a culinary flight of fancy, when it comes to price points Král does not write in a fantastical mode. In this way, he differs from those professional restaurant critics who are about as thrifty as fashion writers describing this season's "must-haves." The emphasis on a fair price for a good portion, consistent throughout the series, shows Král recasting himself as a gourmand of the people. More importantly, it enhances his argument that revelatory gastronomy need not be out of anybody's reach. This feature of the series, however, becomes questionable when the restaurant in question is a thousand kilometers away.

Král praises the atmosphere and service at Chartier, which he describes as "welcoming and homey" and, apart from the high tourism season, the restaurant "belongs predominantly to regulars from the neighborhood" (ibid.). It is precisely in Chartier's everydayness that Král locates its magic.

Something easy and airy marks even the act of paying at Chartier; while the waiter writes the check right on the paper tablecloth, the radiance emanating into the hall through the glass ceiling lights up the tablecloth like a white plane where the waiter's numbers are only a few ephemeral traces. (ibid.)

Král's tone suggests that revenue is an unintended consequence, rather than a driving impetus of Chartier, an impression perhaps made possible by the fact that the restaurant had been in operation for more than a century of uninterrupted capitalism. 
Král's interpretation of the payment procedure, however, reflects his poetic sensibility more than the intentions of Chartier's management. Indeed, as Král notes in an entry on restaurants that appears in his French-language Prague guidebook from 1987, waiters in Czech beer-halls keep track of a customer's tab in just the same way as those at Chartier: by penciling tallies on the paper tablecloths. At Chartier, though, Král notes a unity of service, atmosphere, and food, such as he describes in his mission statement, which for him transforms the act of paying. Because he believes that everything at Chartier "wondrously, reciprocally harmonizes and satisfies the eyes" (ibid.), small flourishes enhance, rather than substitute for, the fundamental dining experience. Here again we see Král's ability to discern magic in the mundane, the very signature of his poetics.

It seems unlikely that Král's readers would visit Chartier simply based on his suggestion; this is Lidové noviny, not the Michelin Guide. Because it does not function effectively as a recommendation, this piece should be considered something other than a straightforward restaurant review, and as such it reveals an important literary facet of Král's project. The Chartier review calls to mind Roland Barthes's analysis of the recipe column in Elle magazine from his book Mythologies. Although written in the recognizable form of recipes, the techniques, ingredients, and most important, aesthetics of the dishes are so fanciful and so far removed from the everyday reality of Elle's readers as to be essentially fictional. Even in a genre that is usually didactic, some texts are meant not to instruct but to inspire. Král's review of Chartier, with its Proustian and Baudelairean undertones, is less a restaurant review than a memory of a poem-excursion.

\section{Czech Gastronomy in the Postcommunist Era}

Using his review of Chartier as the standard, one gets a sense of Král's desires for and disappointments with Czech restaurants in the wake of communism. He reviews none of the Czech restaurants as favorably as he does Chartier, although the time between his visit and his writing may have been a factor. That is to say, Král seems to have entered the Czech restaurants with a critical eye (and tongue) and reviewed them immediately, while the review of Chartier was slowcooked in the search of lost time. In the rest of the series, Král surveys the culinary landscape of contemporary Prague, plus one hotel in Brno, identifying negligence in both preparation and service as a communist leftover.

The Prague restaurant that comes closest to the ideal represented by Chartier is U Šmavy, still in operation as of the writing of this article. ${ }^{8}$ Král begins his review by describing "the secret hope of a traveler when, in the afternoon, he finds himself in an unknown town: that he will find a homey, folksy hospoda where he will taste some real local cuisine and at the same time, among local regulars, get to know a bit of the hidden life of the town" " $U$ Šumavy," November 15). This characterization places U Šumavy not just among authentic, unpretentious restaurants, but connects it with the historical origin of restaurants as such: inns offering nourishment to weary travelers. At U Šumavy: "the servers and waiters are obliging, here you can drink the excellent Budvar $^{9}$ (a half-liter for 14.90 crowns), you can order readymade dishes -in addition to made-to-order-even in the evening ${ }^{10}$ and, most importantly, there is nothing expensive or thoughtless" (ibid.). The restaurant boasts a modest traditional menu. Daily offerings include goulash, fried carp with caraway seeds, and svičková, beef sirloin in creamy gravy with cranberries and bread dumplings. ${ }^{11}$ Rare treats such as wild boar roulade and brain soup appear as specials. Although he champions tradition in both cooking and dining, Král does not hold dogmatically to custom. In his review of Chartier, he describes herring and lamb's head stew as "treasures of traditional French cuisine, slightly improving variations of which may appear, not by chance, even in those 'proper' gourmet establishments" ("Chartier," October 16). Král thus allows for change, provided it occurs organically and represents a true improvement on the original.

Král's review of U Šumavy is not overwhelmingly positive, but his criticism is no less poetic than his praise. In keeping with his emphasis on care and transparency, he notes that "meat or fish sometimes bashfully crouch beside the too large and humdrum piles of potatoes" ("U Šumavy," November 15). Overall, though, the restaurant earns his acclaim because "it is clear that in the kitchen behind the taproom there is someone who chooses for us, that he counts on the delicacy of our little tongues-and so here we are not just given over to anonymous restaurant machinery" (ibid.). In other words, at U Šumavy, the guest does not suffer from neglect. This sentence also contains an understated but colossally important idea: the cultivation of the consumer class.

The Velvet Revolution enabled, even necessitated a cultural transformation as drastic as the political and economic changes it ushered in. Apart from the mission statement and an ironic reference in a diatribe against paltry portions to the state-mandated serving size of meat, the "socialist 100 grams" ("Beseda Bonsai," December 4), Král largely refrains from explicitly political or economic rhetoric, and instead focuses on the aesthetics of transition. Precipitating the rise of a sophisticated restaurant industry in the postcommunist state must be a sophisticated consumer class. Básník má hlad attempts to 


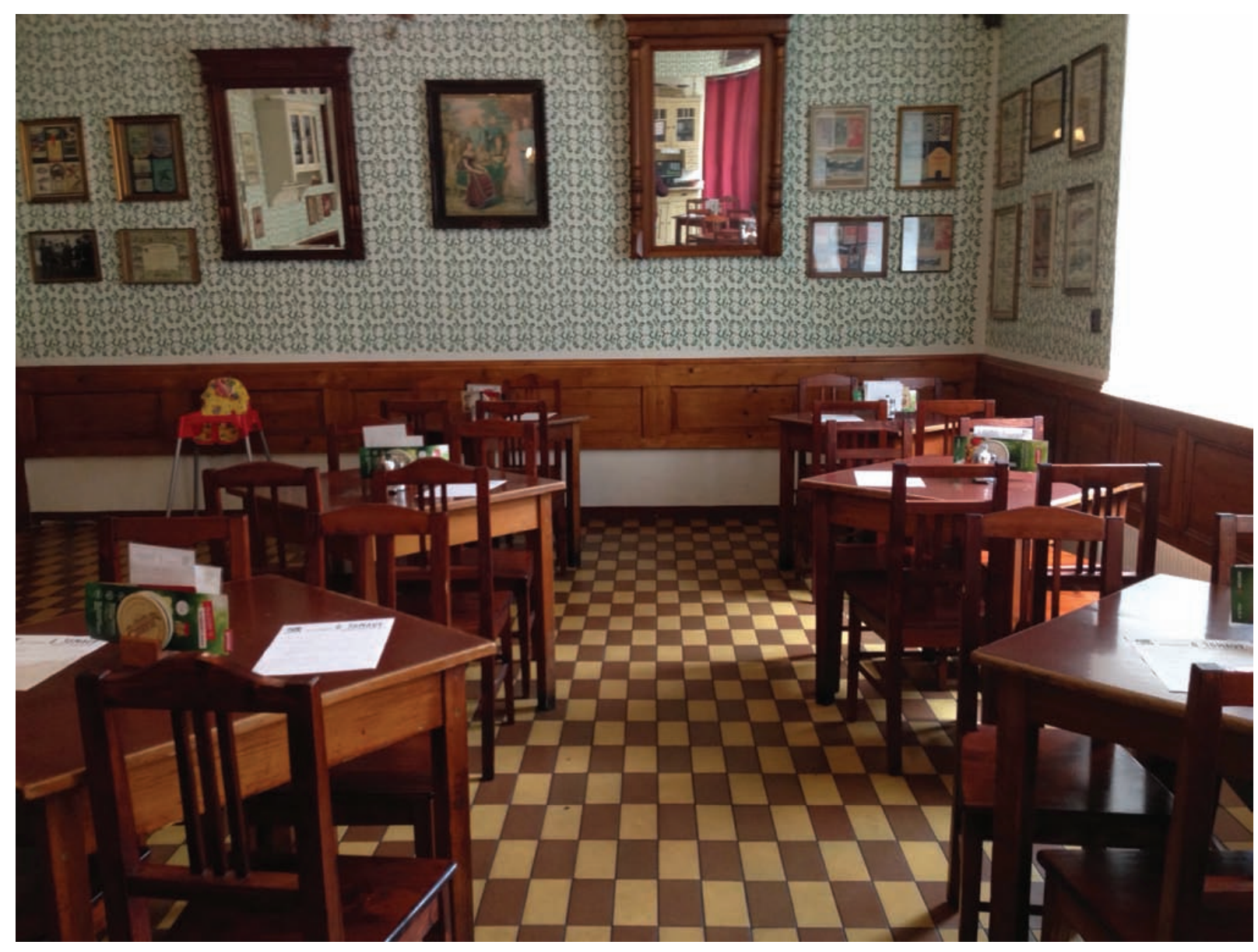

FIGURE 4: U Šumavy, "a homey, folksy hospoda."

PHOTOGRAPH BY ALEX TULLOCK (C) 2017

create that class, to cultivate a more discriminating public palate.

A sophisticated consumer class must be capable of two basic tasks: appreciating quality, such as one finds at $U$ Šumavy, and decrying mediocrity. In its day, Alex Bar was only a twenty-minute walk from U Šumavy, but Král locates it all the way at the other end of the gastronomical spectrum. He finds Alex Bar to be a disturbingly mysterious establishment. In the poem "After Hours" (original title in English) from the 1980s, Král describes "three male silhouettes-profile, coatand three female bodies, each with its own warmth, its bitter taste and its secret / flickering, living glimmer, / which are now only answered by the echo of those glasses, of a few napkins stranded, hardened and bone-white.” In this poem, Král masterfully evokes the mood of a dimly lit dive bar late at night, like an Edward Hopper painting rendered with words. But what is beguiling in poetry is not always pleasant in reality.
When, in his review of Alex Bar, Král describes an ambience quite similar to that of "After Hours," it is to the writer's distinct displeasure.

In terms of atmosphere, service, and food, Alex Bar earns Král's least forgiving review. In every other negative review, Král finds at least one aspect to praise. For example, Bistro Bárta serves uninspired food but in a pleasant enough atmosphere. The Restaurant on Dlouhá Street is "sepulchrally lit" ("Restaurant v Dlouhé," August 21) and the food banal, but the dining experience is redeemed by an inspired waiter. About him Král writes: "Indeed he did not have any guests apart from us (we came around eight), his attention nevertheless felt natural, and moreover obviously testified to-it's something so unusual I am afraid to even say it - a real love of his occupation" (ibid.). Beseda Bonsai is as uneven as its name, half folksy Czech, half trendy Japanese, but "at least they had toothpicks" ("Beseda Bonsai," December 4). 
But in Alex Bar, Král finds only blatant violations of his values without any redeeming qualities.

The food here is unfortunately mysterious only in how incomprehensiblyand pointlessly - it is not good, or at least "nondescript." It is also disproportionately expensive: the fried schnitzel (perhaps veal) I had was 81 crowns and yet was not only banally flimsy and dry, but also apparently had been reheated in a "microwave," in that terrible appliance from which every decent hospoda should stay far away. (In such places where they use it, they should at least give notice beforehand and proportionately lower the price.) ("Alex Bar," October 30)

Král's fury over the microwave is comically exaggerated but the schnitzel incident is legitimately offensive, as the reheating of fried food inevitably results in a conspicuously limp cut of meat. Moreover, schnitzel is, in Král's gastronomic cosmology, an exemplar of hearty Central European cuisine, perfect in its simplicity. It needs no decoration, only fresh and loving preparation. His rant continues:

The garnish, which should improve the dish, in this case only made it worse: green peas and corn with schnitzel is culinary nonsense, which arouses only wrath and naturally also yearning for "classic" schnitzel with potatoes and cucumber salad. This, when well prepared, is a basic yet perfect gastronomic experience, decidedly more sophisticated than the mechanically tacked-on and would-be luxurious garnish. (ibid.)

Král considers the kitchen staff at Alex Bar to be at once apathetic and hollowly provocative. Their updated schnitzel is nothing like the "slightly improving variations" that Král noted at Chartier, but rather an empty gesture toward creativity. But even more objectionable than the poor quality is the pretension. "Nobody expects a selection of delicacies at a bar, only a decent morsel to eat while drinking" (ibid.). The menus in most Prague restaurants feature a section of traditional bar snacks, designated " $k$ pivu" [to go with beer] and including absorbent dishes like marinated cheese, utopenci [pickled sausage], and roasted pork knee. Whether Alex Bar dispensed with or, as with the schnitzel, destroyed such time-tested dishes is unknown. The cook at Alex Bar is the complete opposite of that choosy "someone" in the kitchen at U Šumavy. And so, when Král accuses Alex Bar of being "disproportionately expensive" (ibid.), it is with well-reasoned indignation.

\section{The Sated Poet}

For someone outside the industry, Král offers a good deal of advice on how a restaurant should be run. By reputation, Král is no slouch in the kitchen, and he contributed beautiful recipes for pot-au-feu and entrecôte marchand de vin, traditional and hearty French dishes, to the Literámí Kavárna Řetězová cookbooks. In order for a restaurant to lure such an accomplished home chef through its doors and earn his praise, it must promise not only reliably good food but also an enriching dining experience. Básník má hlad suggests that if a restaurant can elevate the preparation and service of food to the level of gastronomic art, it can transcend its commercial essence.

Read as a whole, the reviews paint a fairly bleak picture of the Prague restaurant scene in the early 1990s. Although writing at a moment of national economic and political transition, Král describes restaurants operating as if the communist system were still in place. The chefs are uninspired and the servers are careless and neglectful. The single exception is the waiter at Restaurant v Dlouhé who "perceptively - and knowledgeably-reacted to our request for a celery salad with the warning that the salad was processed and suggested replacing it with the fresh cabbage salad (at the same price)" ("Restaurant v Dlouhé," August 21). While the restaurant itself may be lacking, here is a server whose enthusiasm and expertise hearken back to the First Republic, or at least Hrabal's I Served the King of England.

Most of the changes to the restaurant industry that Král notes are decidedly unwelcome, such as the widespread use of microwaves and the "disagreeably cramped and uncomfortable chairs, which gained ground at so many new hospody" ("Bistro Bárta," August 17). Such developments are contrary to the natural, organic innovations Král describes when he writes, albeit romantically, about the development of the French restaurant industry. This underscores the fact that Král's project overall is more restorative than revolutionary. The series critiques and challenges the restaurant industry as a whole, lighting a path toward a variant of capitalistic enterprise that is humane and rooted in aesthetics. By hiding an intellectual agenda within an appeal to everyday readers, Král set himself apart from most restaurant reviewers, and from most poets.

Although Král's interest in the restaurant industry is earnest, it would be a mistake to overlook the mischievous aspects of the series. In terms of genre, the reviews bring to mind another French import, the feuilleton: short, often personal and humorous essays published in newspapers. Leading Czech writers have practiced the art of the feuilleton (in Czech, fejeton) since the founding days of Lidové noviny. The genre made a resurgence among dissident writers in the 1970 s and '8os, such as Ludvík Vaculík who, in the late '8os, took to writing feuilletons in public, sitting in restaurants. Král's choice to write in this mode therefore has an undertone of playful political engagement.

Král's restaurant reviews are so consistently infused with comic exaggerations that his critical persona becomes almost parodic. Perhaps the proper place of Básník má hlad is 


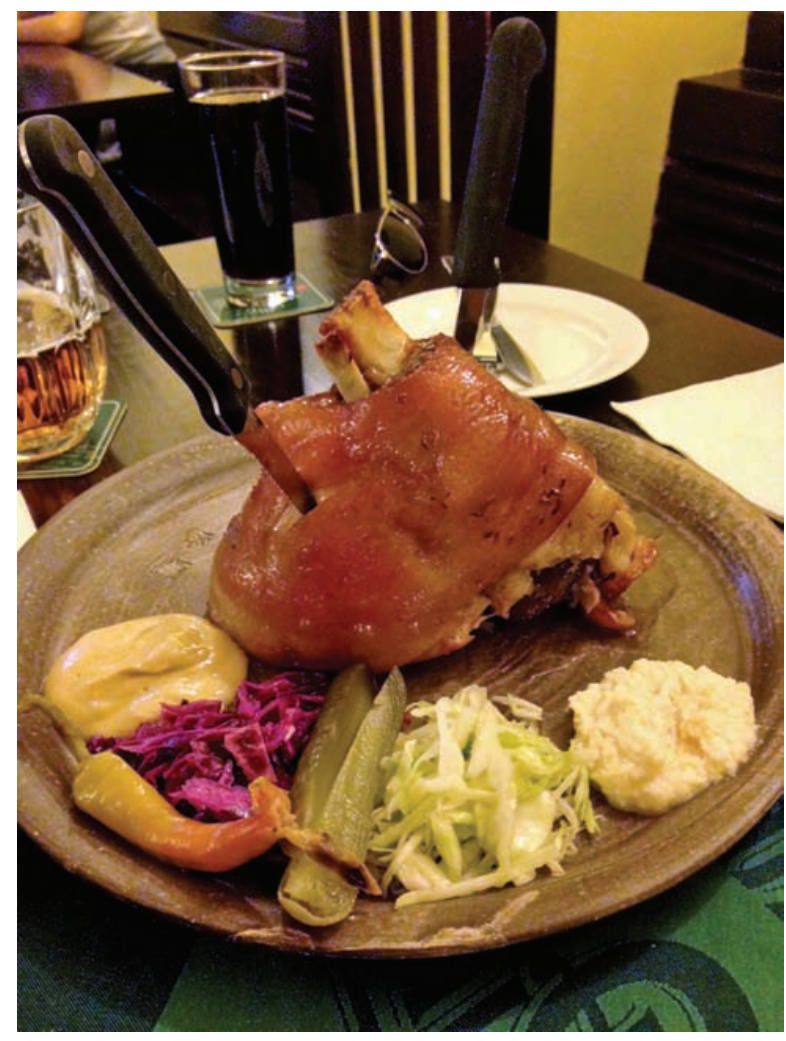

FIGURE 5: Veprové koleno [roasted pork knee] with the traditional accompaniments of horseradish, mustard, and pickles.

PHOTOGRAPH BY ALEX TULLOCK (C) 2017

alongside those great gastro-literary gambols, Marinetti's Futurist Cookbook and Dalîs Les Diners de Gala. The pervasiveness of Král's humor, however, does not require us to read the series as an elaborate joke. It is after all a hallmark of surrealism to transform an everyday object into art simply by removing it from its original context. The casual restaurantgoer and the uninspired restaurateur are perhaps more likely to pick up a newspaper than a volume of poetry, and therein lies Král's surrealist magic trick: art appears where it is not expected.

Admittedly, the reviews did not find much resonance in the world of Czech literature; Král is usually described as a poet, translator, and essayist, not recognized for his achievements as a restaurant critic. But restaurant reviews, now written by a professional cadre, continue to inform the readers of Lidové noviny and other Czech newspapers about where to eat. In the course of writing the series Král did not find his ideal restaurant in Prague, but later he helped to create it: it is the Literární Kavárna Řetězová. Apart for the pátečníci, the Friday afternoon feasts are invitation-only. Nevertheless, during regular business hours, the uninitiated diner can find there "a homey, folksy hospoda, where he will taste some real local cuisine and at the same time, among local regulars, get to know a bit of the hidden life of the town" "Chartier," October 16).

Today, Prague's growing culinary scene is a testament to Král's modest campaign of restoring restaurant culture. Although the pivot to writing restaurant reviews was unusual for a poet, in fact the series was an illuminating project for and about Král. Král's restaurant reviews expressed and enacted the very essence of his poetics: the potential for sublime transcendence that hides in the everyday. There is poetry in the newspaper, in the kitchen, in the process of restoration, waiting for us to discover and cultivate it. @

\section{Acknowledgments}

The research for this article was supported by a grant from the Center for Russian, East European and Eurasian Studies at the University of Texas at Austin. It began as a talk at the conference "Food for Thought: Culture and Cuisine in Russia and Eastern Europe, 180o-Present" at UT Austin in 2014. For their invaluable contributions to this project, I would like to thank Veronika Tuckerova, Mary Neuburger, the faculty and graduate students of the Slavic Department and the librarians at Harvard University, and Phil. Thanks are also due to the reviewers and editorial staff of Gastronomica, especially Managing Editor Rebecca Feinberg. My most heartfelt gratitude goes to Petr Král and the pátečníci, who fed me. Except where otherwise noted, the translations of Král's texts are my own.

\section{NOTES}

1. When I infiltrated the patečníci, in the summer of 2013 , the menu consisted of a cold beet soup (to be compared to borscht only at the diner's great risk), salad of cucumber, tomato, and radish, pork loin, and spaghetti in a light cream sauce with mushrooms. For dessert, there was ice cream with strawberries and whipped cream, vanilla for everyone except the poet Eugen Brikcius who, according to some unspoken agreement, got pistachio. All at once, the guests started clamoring for omáčka [sauce], until the restaurant owner obligingly produced a bottle of grappa, with which we topped our sundaes. 2. Rakvička translates to "little casket," the oblong pastry shell being hollowed out and filled with whipped cream. Another macabre Czech snack is marinated sausages, called utopenci or "drowned men."

3. This phrase is reminiscent of a scene from Daisies, in which one of the two food-crazed heroines wonders, "Why do men say 'I love you'? You know what I mean? Why can't they say, for example, 'egg'?" 4. Collaboration and mutual admiration between French and Czech surrealists dates back to the 1930s. See Derek Sayer's Prague, Capital of the Twentieth Century: A Surrealist History, as well as the final chapter of Peter Demetz's Prague in Black and Gold. 5. Entrusting a poet with a diplomatic role seems fitting for a country that, after all, elected an absurdist playwright as its first president. 
6. Czech has a multitude of words for restaurant. In his reviews, Král deploys the words bar, café, restaurace, pub, kavárna [coffehouse], vinárna [wine bar], pivnice [beer-hall], kantýna [canteen], lokál, výčep, and hospoda, often applying multiple appellations to the same location.

7. Antikody, Havel's 1964 collection of visual poetry, includes a tribute to Slavia: the name Kolár appears at the center of a star-like shape, with the names of writers radiating outward.

8. To date, U Šmavy is the only one of the Prague restaurants Krá reviewed still in operation. Some twenty years after the publication of Král's review, the restaurant is unchanged from his description, right down to the fact that the "tablecloths could really be cleaner, and when placed on the big tables in the back room they should cover more than just the middle part." Through my visit to $U$

Šumavy I appreciated the accuracy and playfulness with which Král described his subject matter. Twenty years later, they are still frying up delicious carp, although I could not muster the guts to order the brains.

9. The namesake of Budweiser, the American "lager" has as much in common with its Czech ancestor as Athens, Tennessee, has with Greece.

10. Hotová jídla or hotovky (ready-made dishes) are cooked in large batches in the morning and served throughout the day. Many classic Czech dishes, such as goulash, can be prepared in this way and thus sold for lower prices than minutky (à la minute or made-toorder dishes). The downside of this system is that the most popular hotovky are apt to run out halfway through dinner service.

11. Whereas most of what constitutes Czech cuisine can be found throughout the former Habsburg lands, svičkova is said to be the only dish truly unique to Bohemia.

\section{REFERENCES}

Ash, Timothy Garten. 1989. "Does Central Europe Exist?" In The Uses of Adversity. New York: Random House.

_ 2009. "Velvet Revolution: The Prospects." New York Review of Books, December 3. Accessed November 23, 2014. www. nybooks.com/articles/archives/2009/dec/03/velvet-revolution-theprospects/.

Barthes, Roland. 1991. "Ornamental Cookery." In Mythologies, trans. Annette Lavers, 78-80. New York: Noonday Press.

"Bouillon Chartier-Home." N.d. Accessed June 25, 2017. www. bouillon-chartier.com/en.

Bourdieu, Pierre. 1984. Distinction: A Social Critique of the Judgement of Taste. Translated by Richard Nice. Cambridge, MA: Harvard University Press.

Caldwell, Melissa L. 2009. "Introduction: Food and Everyday Life after State Socialism." Food and Everyday Life in the Postsocialist World, ed. Melissa Caldwell, 1-28. Bloomington: Indiana University Press.

Demetz, Peter. 1997. Prague in Black and Gold. New York: Hill and Wang.

Ditrych, Břetislav. 2009. "A nakonec rakvičku!” Časopis Host [“And finally a pastry!" Host magazine] 9: 46-49.
Hajdáková, Iveta. 2013. "Discreet Economy: Luxury Hospitality in the Context of Postsocialist Transformation of Czech Society." Laboratorium 1: 73-97.

Hrabal, Bohumil. 2007. I Served the King of England. Translated by Paul Wilson. New York: New Directions.

Kopáč, Radim. 2006. Petr Král: úniky a návraty: Rozhovor. [Petr Král: escapes and returns: A Conversation.] Prague: Filip TomášAkropolis.

Král, Petr. 1983. Ed. and trans., Le surréalisme en tchécoslovaquie. Paris: Gallimard.

—. n.d. "Jaká je Kavárna Arco dnes?" ["What is Café Arco like today?"], Lidové noviny.

- 1987. Prague. Seyssel: Champ Vallon.

—_. 1993. "Alex Bar." Lidové noviny, October zo.

—_. 1993. "Básník má hlad.” Lidové noviny, July 10.

__. 1993. "Beseda Bonsai." Lidové noviny, December 4.

__ . 1993. "Bistro Bárta." Lidové noviny, August 17.

—_. 1993. "Chartier." Lidové noviny, October 16.

_ _ 1993. "Hotel Slavie." Lidové noviny, July 24.

_ . 1993. "Pivnice Radegast." Lidové noviny, September 18.

—_ 1993. "Restaurant v Dlouhé." Lidové noviny, August 21.

_ _ 1993. "U Šumavy." Lidové noviny, November 15.

—_. 1993. "Vinárna U rarášků." Lidové noviny, October 2. - 1996. Soukromý život: Poesie 1982-1985. [Private life: Poetry 1982-1985.] Prague: Mladá fronta.

- 1998. Chiméry a exil. [Chimeras and exile.] Prague: Torst.

_. 2000. Praha. [Prague.] Prague: Karolinum.

_ 2008. "Memory of a Poem-Excursion." Prague Writers'

Festival. Translated by James Naughton. Accessed June 29, 2017 www.pwf.cz/archivy/texts/readings/petr-kral-memory-of-a-poemexcursion_1040.html.

_. 2012a. Cahiers de Paris: Journal 1968-2006. Paris:

Flammarion.

—_. 2012b. "Sláva masu!" In ... a rakvička se šlehačkou, 8-18.

["Glory to meat!" In ... and a pastry with whipped cream] Prague: Týnská literární kavárna.

Kundera, Milan. 1984. "The Tragedy of Central Europe." New York Review of Books, April 26. Accessed August 20, 2014. www.euroculture.upol.cz/dokumenty/sylaby/ Kundera_Tragedy_(18).pdf.

Orzoff, Andrea. 2009. Battle for the Castle: The Myth of Czechoslovakia in Europe, 1914-1948. New York: Oxford University Press.

Sayer, Derek. 2013. Prague, Capital of the Twentieth Century: A Surrealist History. Princeton, NJ: Princeton University Press.

Smith, Jonathan, and Petr Jehlicka. 2007. "Stories around Food, Politics and Change in Poland and the Czech Republic." Transactions of the Institute of British Geographers 32(3): 395-410.

Soukupova, Lenka. 2003. "Assessing the Impacts of Tourism in Post-Socialist Countries: A Case Study of the Czech Republic." $\mathrm{PhD}$ diss., Florida Atlantic University.

Watson, James L., and Melissa L. Caldwell. 2005. In The Cultural Politics of Food and Eating, ed. James L. Watson and Melissa L. Caldwell. Oxford: Blackwell. 